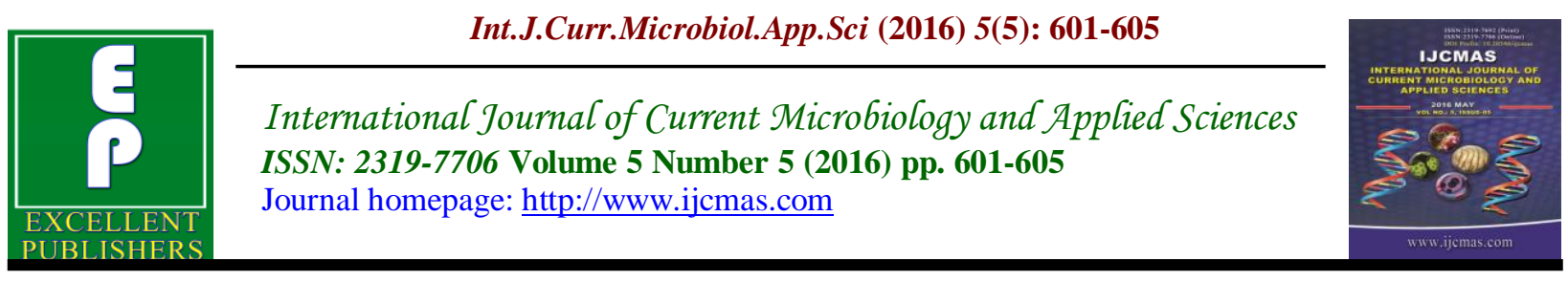

Original Research Article

http://dx.doi.org/10.20546/ijcmas.2016.505.061

\title{
Evaluation of the Physico-chemical and Biological properties of Hydrocarbon Contaminated Soil of Mathura region
}

\author{
Madan Lowry ${ }^{1}$, Mamta Moond ${ }^{1 *}$ and Vikash kumar Boradak ${ }^{2}$ \\ ${ }^{1}$ Department of Zoology (Centre for Advanced studies) / University of Rajasthan, India \\ ${ }^{2}$ Department of Electrical and Electronics Engineering, Manipal University, Jaipur, India \\ *Corresponding author
}

\section{Keywords}

Ecosystem, Hydrocarbon, Indigenous, Micronutrient.

\section{Article Info}

Accepted:

18 April 2016

Available Online:

10 May 2016

\section{A B S T R A C T}

Mathura oil refinery is one of the major oil refineries in India, situated near the Mathura, Uttarpradesh. Hence nearby area of this region was chosen for investigation of soil pollution caused by Crude oil and its counterparts. Soil samples were characterized for various physico-chemical parameters via standard analytical methods. In present investigation augmented values of available Chloride, Bicarbonate, Organic Carbon and Organic Matter, Electric Conductivity, $\mathrm{C} / \mathrm{N}$ ratio were observed in contaminated samples as compared to control samples. While declined values of $\mathrm{pH}$ and WHC were recorded in contaminated samples. Higher content of micronutrients was also observed in polluted samples than uncontaminated one. These accumulated heavy metals adversely distress the ecosystem, both soil and water quality and ultimately harm to health of both flora and fauna by food chain. As hydrocarbon contamination has altered the physical parameters of soil, consequently microbial status of the site is also affected. The indigenous microbial colony was decreased in contaminated samples while petroleum degrading population was found in increased manner as compared to control soil sample.

\section{Introduction}

Accidental discharges of petroleum products are of particular concern in the environment. Hydrocarbon components belong to the carcinogenic and neurotoxic organic pollutant family. Traditional disposal methods i.e. incineration, thermal desorption, land filling, solvent extraction etc, have a number of limitations. As beside their efficiency these processes are expensive and soil loses most of its nutritional value and composition due to execution of these methods. Actually these methods just relocate the problem, as they remove the pollutants from one medium and shuffle it to another means.

In contrast Bioremediation is the biological treatment of these contaminated sites, as it functions mainly on biodegradation. Under biodegradation approach chemical transformation occur mediated by the certain Bacteria, Fungi and plants. Bacteria are ubiquitous, found in all most environmental conditions, so used mostly as natural recycler. (Sharma Shilpi, 2012) These 
microorganisms utilize the complex hydrocarbon contents as carbon and energy source and convert them in simpler harmless form i.e. the complete mineralization of organic contaminations into carbon dioxide, water, inorganic compounds.

Thus the main purpose of present study is to offer the physicochemical and biological parameters of hydrocarbon contaminated soil to speed up the nature's attenuation pathway with the help of microbial degradation.

\section{Material and Method}

\section{Sample Collection}

In present study the soil samples were collected from nearby areas of Mathura oil refinery, Mathura. The sample soil in that particular area was persistently contaminated with petroleum hydrocarbons. The top and sub-soil (4-9 cms of upper surface) samples were collected with a disinfected spatula into a sterilized plastic bag, mixed and accumulated in the laboratory. Soil samples were air dried for 96 hours at room temperature and passed through a $2 \mathrm{~mm}$ sieve.

\section{Physicochemical Study}

\section{Soil Characterization}

Soil physicochemical characteristics such as soil $\mathrm{pH}$, total organic carbon, total organic matter, carbon/nitrogen ratio, total nitrogen, total phosphorus, soil conductivity, WHC and heavy metals were determined. Soil $\mathrm{pH}$ (Pandey and Sharma, 2003) was determined electrometrically. Calcium Carbonate is the insoluble form of carbonates found in soil. Bicarbonates just like Carbonates are very important constituents of soil and are responsible for its buffering capacity.
Bicarbonates can be estimated by using simple acidimetric titrations in the presence of methyl orange as indicator. The HCO3present in the soil gets neutralized by standard acid (Pandey and Sharma, 2003).

WHC refers to the percentage amount of moisture detained by soil in fully saturated condition. Water holding capacity of soil is dependent mainly upon the size and shape of the soil particles and pore sizes. But it is also influenced by the presence of foreign substances, hydrophobic substances like hydrocarbons, which directly or indirectly affects the water holding capacity of soil.

Total organic carbon and matter was determined by method of Walkley and Black (1934). Total nitrogen and $\mathrm{C} / \mathrm{N}$ ratio was determined using the titration method (Subbiash and Asija, 1956). Micronutrients and heavy metals like potassium, magnesium, copper, zinc, manganese, iron and lead was determined by digesting the samples analyzed by the atomic absorption spectrophotometer (AAS).

\section{Microbial Status of the Soil Samples}

The microbial status of the soil samples was observed by enumerating the total heterotrophic bacterial count and petroleum degrading bacterial population. These results were counter checked by measuring the evolved $\mathrm{CO} 2$ and mineralized carbon contents. As live microorganisms present in soil respire and evolve carbon dioxide which can be evaluated as an indicator of microbial activity of particular soil (Dubey and Maheshwari, 2004).

\section{Result and Discussion}

Contaminated soil samples were more acidic than their uncontaminated counterparts. The acidic $\mathrm{pH}$ of contaminated soils may not 
sustain vegetations as acidification of soil reduces essential elements. $\mathrm{pH}$ also influences the solubility and accessibility of soil components which indirectly influence biological activity in the soil (Onojake and Osuji, 2012).

Table.1 Physico-Chemical Parameters of Hydrocarbon contaminated and uncontaminated Soil Samples of Mathura

\begin{tabular}{|c|c|c|c|c|c|c|}
\hline S.No. & Parameter & Unit & $\begin{array}{c}\text { Control } \\
\text { Sample }\end{array}$ & $\begin{array}{c}\text { Sample-1 } \\
(\mathrm{M}-1)\end{array}$ & $\begin{array}{c}\text { Sample-2 } \\
(\mathrm{M}-2)\end{array}$ & $\begin{array}{c}\text { Sample-3 } \\
(\mathrm{M}-3)\end{array}$ \\
\hline 1 & $\mathrm{pH}$ & & 8.42 & 7.04 & 7.08 & 7.17 \\
\hline 2 & $\mathrm{EC}$ & $\mathrm{Dsm}^{-1}$ & 1.16 & 1.33 & 1.20 & 1.36 \\
\hline 3 & Carbonate & $\mathrm{Mg} / 100 \mathrm{gm}$ & $\mathrm{ND}$ & $\mathrm{ND}$ & $\mathrm{ND}$ & $\mathrm{ND}$ \\
\hline 4 & Bicarbonate & $\mathrm{Mg} / 100 \mathrm{gm}$ & 109.8 & 140.3 & 132.0 & 142.5 \\
\hline 5 & $\begin{array}{c}\text { Calcium } \\
\text { Carbonate }\end{array}$ & $\mathrm{Mg} / 100 \mathrm{gm}$ & 4.0 & 8.5 & 8.5 & 10.5 \\
\hline 6 & $\begin{array}{c}\text { Organic } \\
\text { Matter }\end{array}$ & $\%$ & 0.207 & 2.38 & 2.13 & 2.27 \\
\hline 7 & $\begin{array}{c}\text { Organic } \\
\text { Carbon }\end{array}$ & $\%$ & 0.12 & 1.38 & 1.24 & 1.32 \\
\hline 8 & Chloride & $\mathrm{Mg} / 100 \mathrm{gm}$ & 99.4 & 56.8 & 42.6 & 65.85 \\
\hline 9 & $\begin{array}{c}\text { Moisture } \\
\text { Content }\end{array}$ & $\%$ & 0.16 & 0.84 & 0.70 & 0.72 \\
\hline 10 & WHC & $\%$ & 24.66 & 16.64 & 14.58 & 13.65 \\
\hline 11 & $\begin{array}{c}\text { Available } \\
\text { Nitrogen }\end{array}$ & $\mathrm{Mg} / \mathrm{kg}$ & 120 & 535 & 598 & 635 \\
\hline 12 & C/N ratio & $\mathrm{Mg} / \mathrm{kg}$ & $17: 1$ & $28: 1$ & $30: 1$ & $33: 1$ \\
\hline
\end{tabular}

Table.2 Available Micronutrients in Hydrocarbon contaminated and uncontaminated Soil Samples of Mathura

\begin{tabular}{|c|c|c|c|c|c|c|}
\hline S.No. & Parameter & Unit & $\begin{array}{c}\text { Control } \\
\text { Sample }\end{array}$ & $\begin{array}{c}\text { Sample-1 } \\
(\mathrm{M}-1)\end{array}$ & $\begin{array}{c}\text { Sample-2 } \\
(\mathrm{M}-2)\end{array}$ & $\begin{array}{c}\text { Sample-3 } \\
(\mathrm{M}-3)\end{array}$ \\
\hline 1 & Lead & $\mathrm{Mg} / \mathrm{kg}$ & 38 & 288 & 296 & 292.34 \\
\hline 2 & Potassium & $\mathrm{Mg} / \mathrm{kg}$ & 229 & 347 & 232 & 269 \\
\hline 3 & Magnesium & $\mathrm{Mg} / \mathrm{kg}$ & 1360 & 1547 & 1369 & 1500 \\
\hline 4 & Zinc & $\mathrm{Ppm}$ & 8.76 & 15.98 & 14.16 & 15.18 \\
\hline 5 & Copper & $\mathrm{Ppm}$ & 13.4 & 26.6 & 32.27 & 31.2 \\
\hline 6 & Iron & $\mathrm{Ppm}$ & 7.0 & 18.6 & 14.2 & 13.5 \\
\hline 7 & Manganese & $\mathrm{Ppm}$ & 9.94 & 12.4 & 12.2 & 7.58 \\
\hline
\end{tabular}

Table.3 Bacterial Status of contaminated and uncontaminated Soil Samples of Mathura

\begin{tabular}{|c|c|c|c|}
\hline Bacterial count & $\begin{array}{c}\text { Control } \\
\text { Sample }\end{array}$ & $\begin{array}{c}\text { Contaminated } \\
\text { Sample-1 }\end{array}$ & $\begin{array}{c}\text { Contaminated } \\
\text { Sample-2 }\end{array}$ \\
\hline CFU (NA) THBP & $2.85 \times 10^{7}$ & $3.15 \times 10^{5}$ & $1.90 \times 10^{5}$ \\
\hline CFU (MSM) PDBP & $3.36 \times 10^{3}$ & $1.9 \times 10^{4}$ & $2.1 \times 10^{4}$ \\
\hline
\end{tabular}



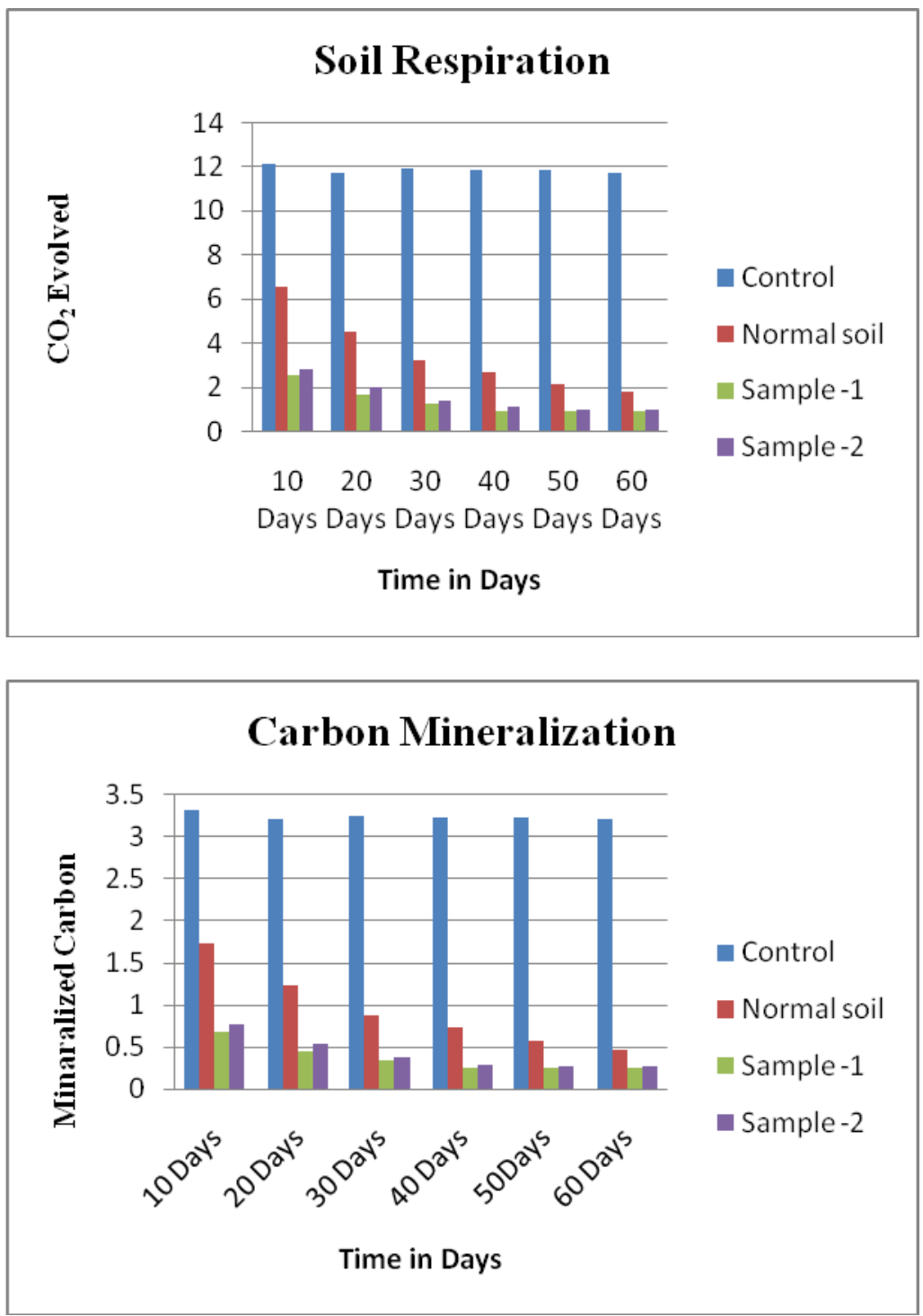

Available Carbonate is absent in contaminated soil samples. Contaminated soil samples had very high bicarbonate content than the control samples. Contaminated soil samples had much higher contents of Chloride as compared to the control soil. As due to oil spillage Hydrocarbons merged with soil, continuous inputs of carbon and hydrogen cause enhanced level of organic carbon and organic matter in the affected sites. High carbon content was recorded in the contaminated sites as compared to the uncontaminated sample. Nitrogen content in the contaminated soil samples was very low than control sample. The $\mathrm{C} / \mathrm{N}$ ratio in the contaminated soils was very high than uncontaminated one.

Available micronutrients $(\mathrm{Pb}, \mathrm{Mg}, \mathrm{K}, \mathrm{Zn}$, $\mathrm{Cu}, \mathrm{Mn}, \mathrm{Fe}$ ) was observed in higher amount in contaminated samples than uncontaminated samples. According to prior investigations, it can be concluded that 
crude oil contamination generally elevates the heavy metal content of the soil. Therefore crop cultivated on such polluted location can cause of bio-accumulation of heavy metals in the population. (Adesina O. Gabriel and Adelasoye A. Kasali, 2014). Though, this study confirms that pollution by crude oil developed some hydrocarbon degrading populations of microorganisms.

From current research by enumerating viable bacterial count it was observed that uncontaminated soil sample indexed maximum heterotrophic bacterial count while contaminated samples had the lower heterotrophic bacterial population. In contrast petroleum degrading bacterial population was registered higher in contaminated samples than their uncontaminated counterparts.

\section{References}

Adesina O. Gabriel and Adelasoye A. Kasali, 2014. Effect of crude oil pollution on heavy metal contents, microbial population in soil, and maize and cowpea growth. Agricultural Sciences. Vol. 5. pp 4350.

Dubey, R.C., Maheshwari, D.K. 2004. Practical microbiology, S. Chand and Company Ltd, New Delhi.

Guala, S.D., Vega, F.A. and Covelo, E.F. (2010). The dynamics of heavy metals in plant soil interaction. Ecological modeling. Vol. 221, pp 1148-1152.

Nazir Ruqia et al, 2015. Accumulation of heavy metals $\mathrm{Ni}, \mathrm{Cu}, \mathrm{Cd}, \mathrm{Cr}, \mathrm{Pb}, \mathrm{Zn}$, $\mathrm{Fe}$ in the soil, water and plants and analysis of physic-chemical parameters of soil and water collected from Tanda dam kohat. J. Pharm.Sci.and Res. Vol. 7(3), pp 8997.

Onojake, M.C. and Osuji, L.C. (2012). Assessment of the physic-chemical properties of hydrocarbon contaminated soil. Scholar research library. Archives of applied science research. Vol 4(1) pp 48-58.

Pandey, J. and Sharma, M.S. (2003). Analysis of soil, in environment science: practical and field manual, Yash publishing House, pp 37-53.

Sharma Shilpi, 2012. Bioremediation: Features, strategies and applications. Asian J. of Pharmacy and Life Sci. Vol 2 (2).

Subbaish B.V. and Asija G.L. (1956). A rapid procedure for the determination of available nitrogen in soils. Current Science. Vol. 25 pp 259-260.

Walkley, A, and Black, I.A. (1934). An examination of the determination method for determining soil organic matter and a proposed modification method of chromic acid titration method. Soil Science. Vol. 34 pp 2938 .

\section{How to cite this article:}

Madan Lowry, Mamta Moond and Vikash kumar Boradak. 2016. Evaluation of the Physicochemical and Biological properties of Hydrocarbon Contaminated Soil of Mathura region. Int.J.Curr.Microbiol.App.Sci.5(5): 601-605. doi: http://dx.doi.org/10.20546/ijcmas.2016.505.061 